\title{
DO PERFORMANCE-BASED PAY AND PAY COMPETITIVENESS MODERATE THE RELATION BETWEEN LOWER-LEVEL EMPLOYEES' TOTAL COMPENSATION AND JOB SATISFACTION? EVIDENCE FROM SOUTH KOREA
}

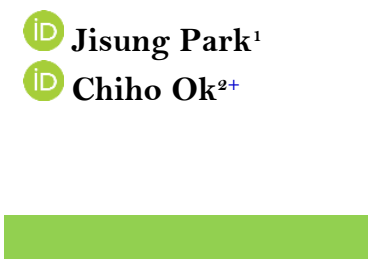

Article History

Received: 26 July 2021 Revised: 10 September 2021

Accepted: 20 October 2021

Published: 7 December 2021

\section{Keywords}

Job satisfaction

Compensation

Performance-based pay

Pay competitiveness

Lower-level employees

South Korea.

\author{
'Associate Professor, College of Business Administration, Chungnam \\ National University, Daejeon, South Korea. \\ Email:jspark1@,cnu.ac.kr \\ 'Assistant Professor, College of Business Administration, Kangwon National \\ University, Chuncheon, South Korea. \\ Email:chiho.ok@kangwon.ac.kr
} ABSTRACT

\begin{abstract}
Decades of international multidisciplinary studies have examined how compensation affects employees and organizations, but they neither specify the boundary conditions for employee job satisfaction nor differentiate the effects of pay on job satisfaction of employees at differing tiers within an organization. We explore whether performancebased pay and pay competitiveness moderate the relation between total compensation and job satisfaction among lower-level employees in South Korea. To investigate boundary conditions for that relation, we use performance-based pay and pay competitiveness as variables that tie compensation structure to job satisfaction. Drawing from data for 2,281 employees at 470 South Korean firms, we consider how two variables-incentive compensation and pay competitiveness-influence job satisfaction of lower-level employees. First, we confirmed a positive relationship between compensation and job satisfaction, and second, we found that the relationship is stronger among employees of firms where average compensation is below what is paid elsewhere.
\end{abstract}

Contribution/Originality: This study contributes to prior research by extending the existing understanding of the effective management of lower-level employees using compensation practices. More specifically, our findings urge companies to consider compensation structure as a means to improve the impact of pay rises on job satisfaction for lower-level employees.

\section{INTRODUCTION}

Compensation is important for both employees and organizations (Gerhart \& Rynes, 2003). For employees, pay not only provides a strong incentive to work, but also allows them to maintain their lives and pursue well-being. For organizations, labor costs are the largest part of the overall cost of operating the organization (Yao, Locke, \& Jamal, 2018). Since the employment relationship between organizations and individuals is also inseparable from pay, pay should be well-managed in the contemporary workplace. In this aspect, numerous researchers around the world in various fields have been studying the effects of pay for the last few decades (Harris, Anseel, \& Lievens, 2008; Judge, Piccolo, Podsakoff, Shaw, \& Rich, 2010; Williams, McDaniel, \& Nguyen, 2006).

Despite this progress, previous approaches to the impact of pay remain underexplored in several ways. First, crystallization of the boundary conditions that lead to employee job satisfaction is needed. Several meta-analyses have shown that the relationship between pay and job satisfaction becomes more prominent depending on the 
characteristics of boundary conditions (Judge et al., 2010). Second, further research should target specific tiers within the organization, such as employees at a lower-level, in order to clarify the differentiating effect on the relationship between pay and job satisfaction. In general, the lower-level employees have limited autonomy as key predictors of job satisfaction due to their roles and responsibilities within the organizational hierarchy, unlike those in the administrative position with high autonomy (Harunavamwe \& Kanengoni, 2013). Regarding this aspect, investigating ways to manage positive attitudes (i.e., job satisfaction) through extrinsic motivation is more important, especially for lower-level employees.

Thus, the main purpose of this study is to investigate the additional boundary conditions on the relationship between pay and lower-level employees' job satisfaction. To do so, we considered two variables related to pay structure, specifically variable pay and pay competitiveness, in the relationship because they are regarded as crucial factors for determining employees' attitudes and perceptions towards pay (Gerhart \& Rynes, 2003). Based on previous studies and relevant theories, we suggested two hypotheses related to the moderating roles of variable pay and pay competitiveness, respectively. By doing so, we intend to contribute to expanding the understanding of prior research on the meaning and impact of pay policy from the perspective of both individuals and organizations.

\section{LITERATURE REVIEW AND HYPOTHESES}

Job satisfaction is defined as “a positive (or negative) evaluative judgment one makes about one's job or job situation" (Weiss, 2002). Conventional wisdom holds that external motivation-money-is a presiding influence on employee job satisfaction, and empirical meta-analyses show that satisfied employees tend to perform well (Harter, Schmidt, \& Hayes, 2002). However, meta-analyses also show that compensation only explains $15 \%$ of the variance in individual job satisfaction (Judge et al., 2010). In other words, higher compensation does not necessarily increase job satisfaction. For that reason, contemporary studies seek the relation between total compensation and job satisfaction in organizational contexts (Judge et al., 2010; Yao et al., 2018). Recent studies have shown that empirical results on the effectiveness of compensation are emerging across cultures and borders (Berliana, Siregar, \& Gustian, 2018; Chan \& Ao, 2019; Darma \& Supriyanto, 2017; Mohamed, Mohamad, \& Awad, 2017; Vizano et al., 2020; Yap Peng Lok, Ng, Kumari, \& Hwa, 2019).

One explanation for the limited impact of total compensation on job satisfaction is that employees see compensation as relative rather than absolute. That is, they compare their total compensation to others within and outside their organizations (Grabner \& Martin, 2021; Gupta, Conroy, \& Delery, 2012). Yang \& Klaas (2011) call discrepancies in compensation for employees at equal levels in the same organization horizontal dispersion and attribute it mostly to performance-based pay. Pay competitiveness involves comparing compensation of employees in similar jobs but in different organizations.

Performance-based pay and pay competitiveness are significant issues for lower-level employees. They want to know how the organization assesses their work, and they see their total compensation as a proxy for their organizational value. Therefore, investigating performance-based pay compared to employees within the organization and pay competitiveness compared to employees outside of the organization clarifies how compensation structure moderates the relationship between total compensation and job satisfaction of lower-level employees.

\subsection{Performance-based Pay for Lower-Level Employees}

Performance-based pay is an incentivized monetary reward for personal, team, or company performance (Huang, 2016). It incentivizes employees work to harder because they receive more compensation for performance. Under the tournament theory (Connelly, Tihanyi, Crook, \& Gangloff, 2014), employees eligible for performancebased pay compete to advance their organizations. Many previous empirical studies show that performance-based pay enhances employees' job satisfaction. Analyzing panel data for 11,849 employees in the United Kingdom, Green 
\& Heywood (2008) found that performance-based pay improved overall job satisfaction and satisfaction with compensation. This effect extends beyond developed western economies (Detnakarin \& Rurkkhum, 2019; Iqbal, Tian, Akhtar, \& Sohu, 2019; Isimoya, Olajide, \& Onafalujo, 2018; Malik, Danish, \& Munir, 2012; Ren, Fang, \& Yang, 2017). Malik et al. (2012) established empirically that performance-based pay enhanced job satisfaction at public and private universities in Pakistan. Ren et al. (2017) also found that pay-for-performance is a significant predictor of positive work attitudes and extra-role behaviors.

Accordingly, we posit that job satisfaction among lower-level employees in South Korea correlates positively and significantly with the percentage of performance-based pay in their total compensation. When the ratio of performance-based pay is low, its effect on job satisfaction should be less. Thus, we present Hypothesis 1.

Hypothesis 1: Performance-based pay affirmatively and directly moderates the relation between total compensation and job satisfaction, and that relation strengthens when performance-based pay is a greater percentage of total compensation.

\subsection{Pay Competitiveness and Lower-Level Employees}

Pay competitiveness involves comparisons between an organization's total compensation and that of its labor market competitors, especially those within the same industry (Guthrie, 2007). Average compensation of organizations with high pay competitiveness exceed those of competitors and imply that they value their workforce (Pfeffer, 1998). All else being equal, employees in firms with high pay competitiveness presumably are more satisfied with their jobs and organizations. Additionally, pay competitiveness helps to retain employees. Under the efficiency wage theory, a compensation premium reduces the relative attractiveness of working elsewhere (Yang \& Klaas, 2011). Based on these arguments, Pfeffer (1998) concluded that causality between wages and organizational success is not likely to be what is generally supposed: it is not that successful organizations pay more, rather, higher-paying organizations succeed.

However, the role of pay competitiveness in the relation between total compensation and job satisfaction can vary. According to the hedonic leveling effect (Lucas, Clark, Georgellis, \& Diener, 2003), equal things can be perceived differently based on the perceiver's conditions. That is, positive events are less likely to affect persons who live well (have less motivation to gain more), but are more likely to affect those whose lives are lacking in some way (have more motivation to gain more). Applying this effect to pay competitiveness suggests that raising salaries enhances job satisfaction among lower-level employees in lower-paying organizations, but that relation may be weak in organizations with high pay competitiveness because their employees already earn comparatively more, reducing satisfaction from incremental rewards. Thus, we propose Hypothesis 2.

Hypothesis 2: Pay competitiveness moderates the positive relation between total compensation and job satisfaction, and that relation is stronger when pay competitiveness is lower.

\section{METHOD}

\subsection{Data and Sample}

We drew nationally representative data from the 2017 wave of South Korea's Human Capital Corporate Panel (HCCP), which interviews 10,000 employees from 470 companies biennially. This data contains individual-level information including lower-level employees and those at higher-levels. To obtain the lower-level employee sample, we only included employees below the status of gwajang (head of a sub-department or section in Korea). Entries with insufficient information regarding wages were excluded, which reduced the final sample to 2,281 employees. The average age of sampled employees was 31.6 years, and $68 \%$ of respondents were male and $32 \%$ were female. The average job tenure was 3.5 years. 


\subsection{Description of Variables}

Job satisfaction: Earlier studies suggest various tools to measure job satisfaction (Price \& Mueller, 1986; Taylor \& Bowers, 1972). Among them, following (Baloglu et al., 2010), we measured job satisfaction using four HCCP items, three items that asked respondents how satisfied they are with their jobs, compensation, and work relationships and a fourth that asked them to rate their overall satisfaction. Respondents rated each on a five-point Likert scale (Cronbach's alpha $=0.82)$. Confirmatory factor analysis supports the validity of the variable $\left(\mathrm{X}^{2}=\right.$ $36.578, \mathrm{p}<0.001$, TLI $=0.972, \mathrm{CFI}=0.991, \mathrm{RMSEA}=0.087)$. We transformed the averages of all four items into a single index of job satisfaction.

Total compensation: The total compensation variable is each employee's annual salary, including fixed and variable compensation, in Korean won converted to units of US\$10,000.

Performance-based pay: Performance-based pay is the proportion of horizontally variable pay (e.g., bonuses, long-term incentive compensation) to total compensation (Merriman \& Deckop, 2007).

Pay competitiveness: Following Yang \& Klaas (2011), we measured pay competitiveness by HCCP data collected by the human resource managers for each company. The managers were asked to reveal the amount of their firms' average total compensation for lower-level employees in their initial year of employment compared to industry peers. They replied on a five-point Likert scale from 1 (lowest in the industry) to 5 (highest in the industry).

Control variables: We controlled for four individual-level effects - gender, age, education, and characteristics of employment. A dummy variable indicates gender $(1=$ male, $\mathrm{o}=$ female). Age is the number of years between an employee's year of birth and 2017. Education was calculated as the total number of years of regular curriculum that they completed during the growth process. To control the differences between occupations, occupational variables were added, which were divided into ten categories, and nine dummy variables were added. Job and organizational tenure are the number of years worked in the same job and in the current organization, respectively. Dummies denote whether respondents worked full-time (1) or part-time (0) at a regular job and did (1) or did not (0) belong to a trade union. The variable of overtime is hours worked beyond the stipulated weekly hours. Perceived compensational fairness is the average of the five-point Likert scores, indicating whether employees believe that their compensation is equitable. Entry-level pay is the average annual salaries for new employees during their initial year of employment. The variable of organizational size is the number of full-time employees at each company. The types of industries for each company were classified as manufacturing, finance, and other industries, which were controlled by the calculation of the manufacturing and financial dummy variables as standard variables.

\subsection{Hierarchical Regression}

We used hierarchical regression to investigate the moderating effects of the performance-based pay variable and pay competitiveness on the relationship between total compensation and job satisfaction. Our reference model (Model 1) includes all control variables, Model 2 includes pay as an independent variable, Model 3 contains an interaction term for pay and performance-based pay to verify the moderating effect of the latter (Hypothesis 1), and Model 4 includes an interaction term for pay and pay competitiveness to verify the moderating effect of the latter (Hypothesis 2). We mean-centered all interaction terms to alleviate multicollinearity.

\section{RESULTS}

\subsection{Descriptive Analysis}

Table 1 shows the means, standard deviations, and correlations of the variables. Job satisfaction correlates positively with pay, performance-based pay, pay competitiveness, gender, perceived fairness, entry-level pay, the banking dummy, and organizational size. It correlates negatively with age, job tenure, organizational tenure, and overtime. 


\begin{tabular}{|c|c|c|c|c|c|c|c|c|c|c|c|}
\hline Variable & Mean & $\begin{array}{l}\text { Std. } \\
\text { Dev. }\end{array}$ & 1 & 2 & 3 & 4 & 5 & 6 & 7 & 8 & 9 \\
\hline 1. Job satisfaction & 3.54 & 0.62 & $(.82)$ & & & & & & & & \\
\hline 2. Total compensation & 3.64 & 1.06 & $0.09^{* * * *}$ & 1.00 & & & & & & & \\
\hline $\begin{array}{l}\text { 3. Performance-based } \\
\text { pay }\end{array}$ & 0.71 & 1.35 & $0.06^{* * * *}$ & $0.30^{* * *}$ & 1.00 & & & & & & \\
\hline 4. Pay competitiveness & 3.05 & 0.80 & $0.12^{* * *}$ & $0.22^{* * *}$ & $0.20^{* * *}$ & 1.00 & & & & & \\
\hline 5. Gender & 0.68 & 0.46 & $0.05^{*}$ & $0.16^{* * *}$ & -0.01 & -0.02 & 1.00 & & & & \\
\hline 6. Age & 31.65 & 4.63 & $-0.08^{* * * *}$ & $0.41^{* * *}$ & 0.02 & -0.02 & $0.21^{* * * *}$ & 1.00 & & & \\
\hline 7. Education & 15.73 & 0.93 & 0.03 & $0.16^{* * * *}$ & $0.04^{*}$ & 0.04 & $0.19^{* * * *}$ & 0.00 & 1.00 & & \\
\hline 8. Job tenure & 3.58 & 3.44 & $-0.07^{* * * *}$ & $0.28^{* * *}$ & $0.06^{* *}$ & -0.00 & $-0.08^{* * * *}$ & $0.49^{* * * *}$ & $-0.18^{* * *}$ & 1.00 & \\
\hline \begin{tabular}{ll|}
9. & Organizational \\
tenure & \\
\end{tabular} & 4.67 & 4.06 & $-0.08^{* * *}$ & $0.45^{* * *}$ & $0.06^{* *}$ & 0.02 & $-0.08^{* * *}$ & $0.65^{* * *}$ & $-0.17^{* * *}$ & $0.75^{* * *}$ & 1.00 \\
\hline 10. Regular job & 0.98 & 0.13 & -0.00 & $0.16^{* * *}$ & 0.01 & 0.01 & $0.10^{* * * *}$ & 0.02 & $0.04^{*}$ & $0.07^{* * * *}$ & $0.08^{* * *}$ \\
\hline 11. Union & 0.11 & 0.31 & 0.02 & $0.15^{* * *}$ & $-0.04^{*}$ & $0.04^{*}$ & 0.00 & $0.08^{* * * *}$ & -0.01 & 0.02 & $0.13^{* * *}$ \\
\hline 12. Overtime & 5.69 & 5.23 & $-0.10^{* * * *}$ & $0.07^{* * * *}$ & -0.00 & -0.00 & $0.11^{* * * *}$ & -0.00 & $0.06^{* *}$ & -0.00 & $-0.04^{*}$ \\
\hline 13. Perceived fairness & 3.25 & 0.89 & $0.55^{* * * *}$ & -0.03 & $0.05^{* *}$ & $0.07^{* * * *}$ & 0.02 & $-0.12^{* * * *}$ & 0.01 & $-0.12^{* * * *}$ & $-0.15^{* * * *}$ \\
\hline 14. Entry-level pay & 32.87 & 6.43 & $0.16^{* * * *}$ & $0.54^{* * * *}$ & $0.25^{* * * *}$ & $0.37^{* * * *}$ & -0.01 & $-0.00^{*}$ & $0.11^{* * * *}$ & 0.01 & $0.10^{* * * *}$ \\
\hline 15. Organizational size & 0.75 & 0.43 & -0.00 & 0.01 & $0.10^{* * *}$ & 0.01 & $0.10^{* * * *}$ & 0.00 & -0.00 & $0.09^{* * *}$ & 0.02 \\
\hline $\begin{array}{ll}16 . & \text { Manufacturing } \\
\text { dummy } & \\
\end{array}$ & 0.05 & 0.21 & $0.07^{* * * *}$ & $0.21^{* * *}$ & -0.01 & $0.06^{* *}$ & $-0.11^{* * * *}$ & -0.03 & -0.02 & -0.02 & 0.03 \\
\hline 17. Banking dummy & 674.96 & 1460.74 & $0.05^{* *}$ & $0.23^{* * *}$ & 0.04 & $0.06^{* *}$ & -0.00 & 0.02 & $0.06^{* * * *}$ & -0.01 & $0.07^{* * *}$ \\
\hline$\overline{\text { Variable }}$ & Mean & $\begin{array}{l}\text { Std. } \\
\text { Dev. }\end{array}$ & 10 & 11 & 12 & 13 & 14 & 15 & 16 & 17 & \\
\hline 10. Regular job & 0.98 & 0.13 & 1.00 & & & & & & & & \\
\hline 11. Union & 0.11 & 0.31 & 0.03 & 1.00 & & & & & & & \\
\hline 12. Extra worktime & 5.69 & 5.23 & $0.05^{* *}$ & 0.00 & 1.00 & & & & & & \\
\hline 13. Perceived fairness & 3.25 & 0.89 & -0.01 & 0.01 & $-0.09^{* * * *}$ & 1.00 & & & & & \\
\hline 14. Entry-level pay & 32.87 & 6.43 & -0.02 & $0.17^{* * * *}$ & $0.06^{* *}$ & $0.07^{* * *}$ & 1.00 & & & & \\
\hline 15. Organizational size & 0.75 & 0.43 & $0.12^{* * * *}$ & $-0.19^{* * * *}$ & $0.04^{*}$ & -0.03 & 0.03 & 1.00 & & & \\
\hline $\begin{array}{ll}16 . & \text { Manufacturing } \\
\text { dummy } & \\
\end{array}$ & 0.05 & 0.21 & -0.01 & $0.30^{* * * *}$ & 0.01 & $0.08^{* * * *}$ & $0.32^{* * * *}$ & $-0.40^{* * * *}$ & 1.00 & & \\
\hline 17. Banking dummy & 674.96 & 1460.74 & 0.00 & $0.14^{* * *}$ & 0.02 & 0.03 & $0.32^{* * * *}$ & $-0.09^{* * * *}$ & $0.17^{* * * *}$ & 1.00 & \\
\hline
\end{tabular}


Table 2. Hierarchical regression results of job satisfaction of lower-level employees.

\begin{tabular}{|c|c|c|c|c|c|c|c|c|c|c|}
\hline \multirow{2}{*}{ Variable } & \multicolumn{2}{|l|}{ Model 1} & \multicolumn{2}{|l|}{ Model 2} & \multicolumn{2}{|l|}{ Model 3} & \multicolumn{2}{|l|}{ Model 4} & \multicolumn{2}{|l|}{ Model 5} \\
\hline & $\mathbf{b}$ & s.e. & $\mathbf{b}$ & s.e. & b & s.e. & b & s.e. & b & s.e. \\
\hline Constant & $1.969^{* * * *}$ & $(0.233)$ & $2.205^{\text {**** }}$ & $(0.239)$ & $2.207^{* * * *}$ & $(0.240)$ & $2.152^{* * * *}$ & $(0.240)$ & $2.145^{* * * *}$ & $\overline{(0.240)}$ \\
\hline Manufacturing sector & -0.007 & $(0.035)$ & -0.002 & $(0.035)$ & -0.001 & $(0.035)$ & 0.005 & $(0.035)$ & 0.006 & $(0.035)$ \\
\hline Finance sector & -0.093 & $(0.072)$ & -0.109 & $(0.072)$ & -0.116 & $(0.072)$ & -0.094 & $(0.072)$ & -0.097 & $(0.072)$ \\
\hline Organizational size & -0.000 & $(0.000)$ & -0.000 & $(0.000)$ & -0.000 & $(0.000)$ & -0.000 & $(0.000)$ & -0.000 & $(0.000)$ \\
\hline Gender & $0.087^{* *}$ & $(0.026)$ & $0.068^{* *}$ & $(0.026)$ & $0.066^{*}$ & $(0.026)$ & $0.068^{*}$ & $(0.026)$ & $0.067^{*}$ & $(0.026)$ \\
\hline Age & -0.005 & $(0.003)$ & $-0.008^{*}$ & $(0.003)$ & $\begin{array}{l}-0.009^{*} \\
*\end{array}$ & $(0.003)$ & $-0.008^{*}$ & $(0.003)$ & $-0.008^{*}$ & $(0.003)$ \\
\hline Education & 0.004 & $(0.012)$ & 0.003 & $(0.012)$ & -0.004 & $(0.012)$ & -0.004 & $(0.012)$ & -0.004 & $(0.012)$ \\
\hline Majored dummies & \multicolumn{2}{|l|}{ Included } & \multicolumn{2}{|l|}{ Included } & \multicolumn{2}{|l|}{ Included } & \multicolumn{2}{|l|}{ Included } & \multicolumn{2}{|l|}{ Included } \\
\hline Job dummies & \multicolumn{2}{|l|}{ Included } & \multicolumn{2}{|l|}{ Included } & \multicolumn{2}{|l|}{ Included } & \multicolumn{2}{|l|}{ Included } & \multicolumn{2}{|l|}{ Included } \\
\hline Job tenure & -0.000 & $(0.004)$ & -0.000 & $(0.004)$ & 0.001 & $(0.004)$ & 0.001 & $(0.004)$ & 0.001 & $(0.004)$ \\
\hline Organization tenure & 0.002 & $(0.005)$ & -0.003 & $(0.005)$ & -0.003 & $(0.005)$ & -0.003 & $(0.005)$ & -0.003 & $(0.005)$ \\
\hline Regular job & -0.010 & $(0.079)$ & -0.072 & $(0.081)$ & -0.078 & $(0.081)$ & -0.078 & $(0.080)$ & -0.079 & $(0.081)$ \\
\hline Union & 0.020 & (0.037) & 0.024 & (0.037) & 0.021 & $(0.037)$ & 0.021 & $(0.037)$ & 0.020 & (0.037) \\
\hline Overtime & $-0.006^{* *}$ & $(0.002)$ & $-0.006^{\text {**** }}$ & $(0.002)$ & $\begin{array}{l}-0.007^{*} \\
* *\end{array}$ & $(0.002)$ & $-0.007^{* * * *}$ & $(0.002)$ & $-0.007^{* * *}$ & $(0.002)$ \\
\hline Perceived compensation fairness & $0.376^{* * *}$ & $(0.012)$ & $0.377^{* * *}$ & $(0.012)$ & $0.378^{* * * *}$ & $(0.012)$ & $0.375^{* * * *}$ & $(0.012)$ & $0.376^{* * * *}$ & $(0.012)$ \\
\hline Entry-level pay & $0.013^{* * * *}$ & $(0.001)$ & $0.008^{* * * *}$ & $(0.002)$ & $\begin{array}{l}0.008^{* * * *} \\
*\end{array}$ & $(0.002)$ & $0.006^{* *}$ & $(0.002)$ & $0.006^{* * * *}$ & $(0.002)$ \\
\hline Total compensation (TC) & & & $0.064^{* * *}$ & $(0.015)$ & $0.071^{* * *}$ & $(0.016)$ & $0.068^{* * * *}$ & $(0.015)$ & $0.069^{* * * *}$ & $(0.016)$ \\
\hline Performance-based pay (PP) & & & & & -0.007 & $(0.010)$ & & & -0.007 & $(0.010)$ \\
\hline $\mathrm{TC} \times \mathrm{PP}$ & & & & & -0.002 & $(0.004)$ & & & 0.000 & $(0.004)$ \\
\hline Pay competitiveness (PC) & & & & & & & $0.033^{*}$ & $(0.014)$ & $0.034^{*}$ & $(0.014)$ \\
\hline $\mathrm{TC} \times \mathrm{PC}$ & & & & & & & $-0.030^{*}$ & $(0.012)$ & $-0.029^{*}$ & $(0.013)$ \\
\hline$R^{2}$ & & 0.338 & & 0.343 & & 0.343 & & 0.346 & & 0.346 \\
\hline Adj. $R^{2}$ & & 0.330 & & 0.335 & & 0.335 & & 0.337 & & 0.337 \\
\hline$F$-value & & $42.61^{* * * *}$ & & $42.04^{* * * *}$ & & $39.28^{* * * *}$ & & $39.73^{* * * *}$ & & $37.24^{* * * *}$ \\
\hline
\end{tabular}

Note: Unstandardized coefficients (b) are reported, and parentheses indicate standard errors (se) $\mathrm{N}=2,281,{ }^{*} \mathrm{p}<0.05,{ }^{* * *} \mathrm{p}<0,01, * * *<<0.001$ 


\subsection{Hypotheses Testing}

Hypothesis 1 posits that performance-based pay moderates any positive relation between pay and job satisfaction. We entered control variables from Table 2 into Model 1 and the pay variable from Table 2 into Model 2. This confirms a positive relation between pay and job satisfaction. To test Hypothesis 1, we entered the performance-based pay variable and the interaction terms of pay and performance-based pay from Table 2 into Model 3. The interaction term is not significant $(b=-0.002, p=0.632)$, and Hypothesis 1 is rejected.

Hypothesis 2 posits that pay competitiveness diminishes the positive relation between pay and job satisfaction. To test that possibility, we entered the pay competitiveness variable and the interaction term of pay and pay competitiveness from Table 2 into Model 4. The results confirm that the interaction term is negative and significant $(b=-0.030, p<0.05, t=-2.47)$.

Figure 1 shows that the relation between pay and job satisfaction strengthens when pay competitiveness is high $(-1 \mathrm{SD}, t=5.37, p<0.001$ for results of the slope difference test) rather than low $(+1 \mathrm{SD}, t=3.139, p<0.01$ for results of the slope difference test).

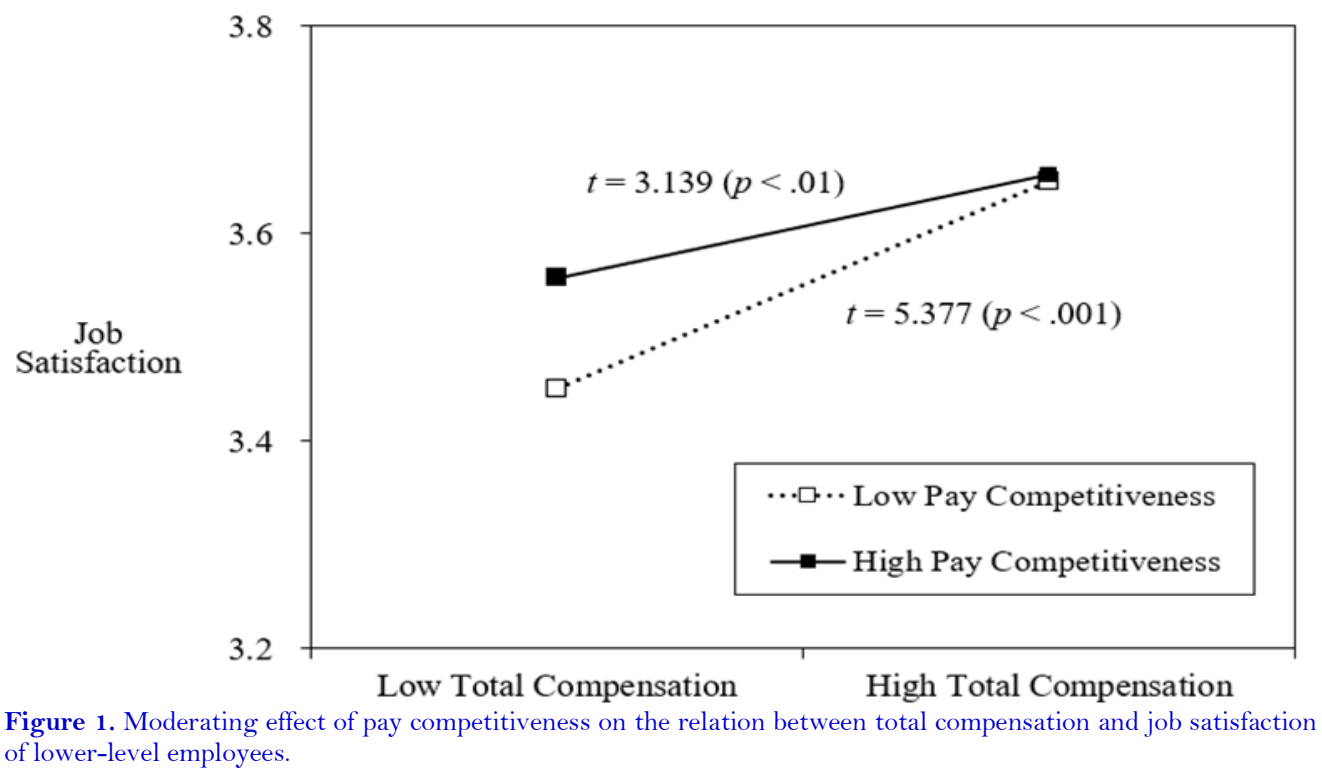

We employed the Johnson-Neyman technique to check the statistical significance of the regions of confidence bands for the moderator (pay competitiveness), as seen in Table 3 (Johnson \& Neyman, 1936; Preacher, Curran, \& Bauer, 2006). At a 0.05 confidence level, the moderator's region of significance spans from 1.00 to 4.12 , indicating that any simple slope within this range is statistically significant. Given that pay competitiveness tracks a five-point scale in one-point units, the positive effect of pay on job satisfaction is significant within 1.00 (which means that the pay competitiveness is the lowest in the industry) to 4.00 (which means that the pay competitiveness is near the industry high). When pay competitiveness reaches 5.00 (which means that the pay competitiveness of the company is the highest in the industry), the positive relation between pay and job satisfaction loses statistical significance. These results reaffirm Hypothesis 2.

Table 3. Conditional effect of the focal predictor at values of the pay competitiveness.

\begin{tabular}{l|c|c|c|c|c|c}
\hline Pay Competitiveness & Effect & S.E. & t-value & p-value & LLCI & ULCI \\
\hline 1. Lowest in the industry & 0.130 & 0.031 & 4.144 & 0.000 & 0.068 & 0.191 \\
\hline 2. Near the industry low & 0.099 & 0.021 & 4.645 & 0.000 & 0.057 & 0.141 \\
\hline 3. Average of the industry & 0.068 & 0.015 & 4.460 & 0.000 & 0.038 & 0.098 \\
\hline 4. Near the industry high & 0.038 & 0.018 & 2.111 & 0.034 & 0.002 & 0.073 \\
\hline 5. Highest in the industry & 0.007 & 0.026 & 0.271 & 0.786 & -0.045 & 0.059 \\
\hline
\end{tabular}




\section{DISCUSSION AND CONLCUSION}

\subsection{Research Summary}

We analyzed how performance-based pay and pay competitiveness affect the relation between pay and job satisfaction of 2,281 lower-level employees in South Korea. Analysis of the sample revealed that the relation is stronger when pay competitiveness is low. Contrary to our prediction, the moderating role of performance-based pay is not verified.

\subsection{Theoretical and Practical Implications}

This study advances scholars' and practitioners' understanding of how compensation affects job satisfaction of lower-level employees in South Korea. First, it confirmed the positive relation between pay and job satisfaction for lower-level employees. Similar to a study by Judge et al. (2010), which performed meta-study on the relationship between pay and job satisfaction and concluded that the relation is positively correlated. The study also showed the effect of total compression, which positively affects job satisfaction. In particular, it is noteworthy that the results of the study are limited to the sampled lower-level employees in Korea, which showed similar positive effects of total compensation on job satisfaction. As a result, similar to the empirical analysis results of many prior studies, if all the other conditions were controlled, this study shows that the positive impact of compensation on job satisfaction is generalizable for lower-level employees in Korea.

Second, the results indicate that managers should consider implementing a pay structure to improve lowerlevel employee satisfaction by raising individual compensation. Per our results, compensation, as an influence on job satisfaction, depends on pay structure, such as pay competitiveness. Although our results identified a causal relation between total compensation and job satisfaction, the relation is not significant for all firms. The result of JohnsonNeyman technique, which tested the regions of confidence bands for pay competitiveness, also supported this explanation, and indicated that the positive relationship between pay and job satisfaction was no longer significant if the pay competitiveness was 5.0 on the scale (the average of a firm's pay was at the highest level within the industry). These results also relate to the seven practices of high-performance work systems used by Pfeffer (1998); it is recommended to offer higher pay rather than performance-based pay. In other words, relative wages provided on a performance basis do not have a very positive impact on employees if the wage level is already high for employees. Our results also support hedonic leveling, i.e., paying lower-level employees more does not increase their job satisfaction if their firms are the industry's highest-paying. Prior studies that relate pay and job satisfaction disregard pay competitiveness. Therefore, the level or intensity of performance-based pay given to lowlevel employees is not very strong. Because of this trend, the effect of performance-based pay on low-level employees can be minimal.

Third, the effect of performance-based pay on lower-level employees' job satisfaction was not revealed in this study. Unlike many prior studies that proved the effectiveness of performance-based pay, this study, which was conducted on lower-level employees in South Korea, found neither a direct effect of relative pay on job satisfaction nor an interaction effect with total compensation. One of the reasons for these results may be the labor market characteristics of South Korea. In the case of companies in South Korea that generally prefer the internal labor market, seniority and position are the most important in determining wages (Froese, 2020).

\subsection{Limitations and Future Research}

Due to this study's limitations, future research is recommended. First, common method variance may be a concern because our data originated from one source. In future studies, longitudinal studies that reflect time-lagged effects, or panel studies that consist of repeatedly investigated samples, should be performed to overcome these limitations. Second, we did not control for whether employees' psychological perceptions or attitudes related to pay (Ren et al., 2017; Selar, Falkenberg, Hellgren, Gagné, \& Sverke, 2020). For example, some employees may be more 
sensitive to monetary compensation, such as wages, while others may want more non-monetary compensation, such as additional paid leave (Froese, Peltokorpi, Varma, \& Hitotsuyanagi-Hansel, 2019). For example, as Maslow's hierarchy of needs theory claims, the effect of compensation on individuals' satisfaction may vary depending on the desired step required by each employee. Therefore, future studies need to identify the impact of wages on satisfaction by closely considering or controlling the circumstances faced by each individual. Third, prior studies emphasized the effect of actual pay on employees' attitudes and behavior alongside their perceptions of actual pay, but we disregarded that issue (Yao et al., 2018). Information on the exact absolute wage of an individual is very difficult to obtain, so while these studies are quite challenging, these attempts should certainly be viable in future studies. Finally, future studies should replicate our findings in diverse cultures for generalizability. In particular, further research is needed on whether the results for lower-level employment are similar not only in Korea but also in other countries. This is because the difference between generations that occurs over time is a characteristic that is common among humans in general, regardless of location.

Funding: This study received no specific financial support.

Competing Interests: The authors declare that they have no competing interests.

Acknowledgement: Both authors contributed equally to the conception and design of the study.

\section{REFERENCES}

Baloglu, S., Erdem, M., Brewer, P., Mayer, K., McCain, S. L. C., Tsai, H., \& Bellino, N. (2010). Organizational justice, employees' ethical behavior, and job satisfaction in the casino industry. International Journal of Contemporary Hospitality Management, 22(7), 992-1009.

Berliana, M., Siregar, N., \& Gustian, H. D. (2018). The model of job satisfaction and employee performance. International Review of Management and Marketing, 8(6), 41-46.

Chan, S. H. J., \& Ao, C. T. D. (2019). The mediating effects of job satisfaction and organizational commitment on turnover intention, in the relationships between pay satisfaction and work-family conflict of casino employees. Journal of Quality Assurance in Hospitality \& Tourism, 20(2), 206-229. Available at: https://doi.org/10.1080/1528008x.2018.1512937.

Connelly, B. L., Tihanyi, L., Crook, T. R., \& Gangloff, K. A. (2014). Tournament theory: Thirty years of contests and competitions. Journal of Management, 4O(1), 16-47. Available at: https://doi.org/10.1177/0149206313498902.

Darma, P. S., \& Supriyanto, A. S. (2017). The effect of compensation on satisfaction and employee performance. Management and Economics Journal (MEC-J), 1(1), 1-10.

Detnakarin, S., \& Rurkkhum, S. (2019). Pay-for-performance and organizational citizenship behavior in Thai hotels: The mediating role of perceived organizational support. Humanities, Arts and Social Sciences Studies, 19(2), 340-361.

Froese, F. J., Peltokorpi, V., Varma, A., \& Hitotsuyanagi-Hansel, A. (2019). Merit-based rewards, job satisfaction and voluntary turnover: Moderating effects of employee demographic characteristics. British Journal of Management, 30(3), 610-623.

Froese, F. J. (2020). Ready for global success? Strengths and weaknesses of Korean HRM. Asian Business \& Management, 19(2), 179-183.

Gerhart, B., \& Rynes, S. (2003). Compensation: Theory, evidence, and strategic implications. New York: Sage.

Grabner, I., \& Martin, M. A. (2021). The effect of horizontal pay dispersion on the effectiveness of performance-based incentives. Accounting, Organizations and Society, 88, 101174. Available at: https://doi.org/10.1016/j.aos.2020.101174.

Green, C., \& Heywood, J. S. (2008). Does performance pay increase job satisfaction? Economica, 75(300), 710-728.

Gupta, N., Conroy, S. A., \& Delery, J. E. (2012). The many faces of pay variation. Human Resource Management Revierw, 22(2), 100115.

Guthrie, J. P. (2007). Remuneration: Pay effects at work. In Boxall, P., Purcell, J., and Wright, P. (eds.), Oxford Handbook of Human Resource Management. New York: Oxford University Press. 
Harris, M. M., Anseel, F., \& Lievens, F. (2008). Keeping up with the Joneses: A field study of the relationships among upward, lateral, and downward comparisons and pay level satisfaction. Journal of Applied Psychology, 93(3), 665-673. Available at: https://doi.org/10.1037/002 1-9010.93.3.665.

Harter, J. K., Schmidt, F. L., \& Hayes, T. L. (2002). Business-unit-level relationship between employee satisfaction, employee engagement, and business outcomes: A meta-analysis. Journal of Applied Psychology, 87(2), 268-279. Available at: https://doi.org/10.1037/002 1-9010.87.2.268.

Harunavamwe, M., \& Kanengoni, H. (2013). The impact of monetary and non-monetary rewards on motivation among lower level employees in selected retail shops. African Journal of Business Management, 7(38), 3929-3935.

Huang, W. (2016). Responsible pay: managing compliance, organizational efficiency and fairness in the choice of pay systems in China's automotive companies. The International Journal of Human Resource Management, 27(18), 2161-2181.

Iqbal, S., Tian, H., Akhtar, S., \& Sohu, J. (2019). Impacts of performance-based pay on employee productivity; Mediated by employee training. International Journal of Research and Review, 6(10), 235-241.

Isimoya, O. A., Olajide, O. T., \& Onafalujo, A. K. (2018). Performance related pay and organizational commitment-evidence from Nigeria. Journal of Economics \& Management, 34(4), 58-80.

Johnson, P. O., \& Neyman, J. (1936). Tests of certain linear hypotheses and their application to some educational problems. Statistical Research Memoirs, 1(1), 57-93.

Judge, T. A., Piccolo, R. F., Podsakoff, N. P., Shaw, J. C., \& Rich, B. L. (2010). The relationship between pay and job satisfaction: A meta-analysis of the literature. Journal of Vocational Behavior, 77(2), 157-167.

Lucas, R. E., Clark, A. E., Georgellis, Y., \& Diener, E. (2003). Reexamining adaptation and the set point model of happiness: Reactions to changes in marital status. Journal of Personality and Social Psychology, 84(3), 527-539. Available at: https://doi.org/10.1037/0022-3514.84.3.527.

Malik, M. E., Danish, R. Q., \& Munir, Y. (2012). The impact of pay and promotion on job satisfaction: Evidence from higher education institutes of Pakistan. American Journal of Economics, 2(4), 6-9. Available at: https://doi.org/10.5923/j.economics.20120001.02.

Merriman, K. K., \& Deckop, J. R. (2007). Loss aversion and variable pay: A motivational perspective. The International Journal of Human Resource Management, 18(6), 1026-1041. Available at: https://doi.org/10.1080/09585190701321591.

Mohamed, A. A., Mohamad, M. S., \& Awad, A. E. (2017). The relationship between pay satisfaction and turnover intention in Egypt. Journal of Competitiveness Studies, 25(1), 65-79.

Pfeffer, J. (1998). The human equation: Building profits by putting people first. Boston, MA: Harvard Business Press.

Preacher, K. J., Curran, P. J., \& Bauer, D. J. (2006). Computational tools for probing interactions in multiple linear regression, multilevel modeling, and latent curve analysis. Journal of educational and behavioral statistics, 31(4), 437-448. Available at: https://doi.org/10.3102/10769986031004437.

Price, J. L., \& Mueller, C. W. (1986). Handbook of organizational measurement. Marshfield, MA: Pitman Publishing.

Ren, T., Fang, R., \& Yang, Z. (2017). The impact of pay-for-performance perception and pay level satisfaction on employee work attitudes and extra-role behaviors: An investigation of moderating effects. Journal of Chinese Human Resource Management, 8(2), 94-113. Available at: https://doi.org/10.1108/jchrm-06-2015-0012.

Selar, N. A., Falkenberg, H., Hellgren, J., Gagné, M., \& Sverke, M. (2020). “It’s [not] all 'bout the money”: How do performancebased pay and support of psychological needs variables relate to job performance? Scandinavian Journal of Work and Organizational Psychology, 5(1), 1-14.

Taylor, J. C., \& Bowers, D. G. (1972). Survey of organizations: A machine scored standardized questionnaire instrument. Ann Arbor, MI: Institute for Social Research, University of Michigan.

Vizano, N. A., Utami, W., Johanes, S., Herawati, A., Aima, H., Sutawijaya, A. H., . . Setiyani, A. (2020). Effect of compensation and organization commitment on tournover intention with work satisfaction as intervening variable in indonesian industries. Systematic Reviews in Pharmacy, 11 (9), 287-298. 
Weiss, H. M. (2002). Deconstructing job satisfaction: Separating evaluations, beliefs and affective experiences. Human Resource Management Review, 12(2), 173-194.

Williams, M. L., McDaniel, M. A., \& Nguyen, N. T. (2006). A meta-analysis of the antecedents and consequences of pay level satisfaction. Journal of Applied Psychology, 91(2), 392-413. Available at: https://doi.org/10.1037/002 1-9010.91.2.392.

Yang, H., \& Klaas, B. S. (2011). Pay dispersion and the financial performance of the firm: Evidence from Korea. The International Journal of Human Resource Management, 22(10), 2147-2166. Available at: https://doi.org/10.1080/09585192.2011.580182.

Yao, Y. H., Locke, E. A., \& Jamal, M. (2018). On a combined theory of pay level satisfaction. Journal of Organizational Behavior, 39(4), 448-461. Available at: https://doi.org/10.1002/job.2243.

Yap Peng Lok, S., Ng, L. C., Kumari, P., \& Hwa, E. P. (2019). The impact of compensation system on pay satisfaction in the banking industry in Malaysia: A proposed framework. Global Business \& Management Research, 11(2), 61-72. 